\title{
Hourly to daily-scale microtopographic fluctuations of supratidal sandstone
}

Runjie Yuan, ${ }^{1 \star}$ David M. Kennedy ${ }^{1}$ and Wayne J. Stephenson ${ }^{2}$

${ }^{1}$ School of Geography, The University of Melbourne, Parkville Vic 3010, Australia

${ }^{2}$ Department of Geography, The University of Otago, Dunedin, New Zealand

*Corresponding Author, runjiey@student.unimelb.edu.au, +61 383449168

This is the author manuscript accepted for publication and has undergone full peer review but has not been through the copyediting, typesetting, pagination and proofreading process, which may lead to differences between this version and the Version of Record. Please cite this article as doi: $10.1002 /$ esp.4476

This article is protected by copyright. All rights reserved. 


\section{ABSTRACT}

A traversing micro-erosion meter (TMEM) was used to measure short-term microtopographic changes on a supratidal rock surface at Marengo, Australia. In order to describe the characteristics of rock surface behaviour at different temporal scales, the TMEM site was monitored at 2-hourly, daily and multiday (3.5 days) periods. The rock surface was highly dynamic at 2-hourly scale, repeatedly falling and rising by up to 0.644 $\mathrm{mm}$. Two-hourly surface change was also characterised by spatial heterogeneity, with contraction and expansion occurring concurrently at centimetre scale across the rock surface. Two-hourly microtopographic change was linked to the microclimate with significant relationships between surface movement and relative humidity $\left(R^{2}=0.27\right)$ and air temperature $\left(R^{2}=0.24\right)$. Expansion was observed across the rock surface when there was a fluctuation of $18 \%$ in relative humidity, and when cloudy the rock surface remained active during the day. Temporal variability in surface movement was also observed over a 24-hour period with three distinct periods observed: falling (06:00 - 12:00), rising (12:00 20:00) and stable (20:00 - 06:00). The daily surface change underwent no net microtopographic change (no loss of material). In contrast, an overall contraction was observed at multiday scale. Rock surface behaviour in coastal environments is therefore complex with many cycles of expansion and contraction acting concurrently albeit at different temporal scales from hours to multiple days. 
KEYWORDS: traversing micro-erosion meter; sandstone; surface microtopography; rock decay; subaerial microclimate

\section{Introduction}

Shore platforms are erosional landforms frequently found on rocky coasts, resulting from subaerial cliff retreat (Trenhaile, 1987; Sunamura, 1992). Driven by marine and subaerial processes, the development of shore platforms is caused mainly by erosion mechanisms such as joint block removal occurring at the meso-scale (cm to m) (Trenhaile, 1972; Naylor and Stephenson, 2010; Stephenson and Naylor, 2011a; Stephenson and Naylor, 2011b) and granular disintegration at the micro-scale $(\mathrm{mm}$ to $\mathrm{cm}$ ) (Stephenson and Kirk, 2000; Porter et al., 2010), when averaged over centennial to millennial scales intertidal shore platforms hundreds of meters wide can develope (Kennedy et al., 2017). The balance between marine and subaerial processes in driving this erosion is highly varied and site specific (Kennedy et al., 2011; Stephenson, 2013) with the relative importance of subaerial processes increasing with distance from the sea (Kanyaya and Trenhaile, 2005). At the micro-scale, subaerial rock decay is often responsible for increasing rock surface roughness through the development of pits, tafoni and karren (Gómez-Pujol et al., 2006).

Granular disintegration is of particular significance in the lowering of shore platforms formed in homogenous bedrock where widely spaced joints inhibit direct wave plucking of blocks (Stephenson and Kirk, 1996; Naylor and Stephenson, 2010; Trenhaile and Porter, 2018). The detachment of particles from a rock surface however often requires a degree of 
rock decay to loosen individual grains. This may include dissolving of cements (Brantley, 2010) or oxidation and hydrolysis of specific minerals (Luquot et al., 2014). Often erosion is precursed by the microtopography change of rock surfaces, which generates stress to promote granular disintegration (Stephenson et al., 2004; Porter et al., 2010). The scale of microtopography change generally ranges, in the vertical plane, from 0.01 to $1 \mathrm{~mm}$ but can up to $8.9 \mathrm{~mm}$ (Stephenson and Kirk, 2001). Critically, this rock surface change is comparable to the global average rate of platform surface downwearing of $1.486 \mathrm{~mm} / \mathrm{yr}$ (Stephenson and Finlayson, 2009). This means studies of only a few years duration need to account for shorter term fluctuations, as data may not reflect an overall erosion trend but rather a short-term surface dynamic (Gómez-Pujol et al., 2007).

The temporal scale of microtopography change events has been measured to occur from hours to years (Stephenson et al., 2004). To identify the drivers of this microtopographic change, a number of studies of hourly surface movement have been conducted on a range of lithologies, including sandstone, limestone, basalt and mudstone (Gómez-Pujol et al., 2007; Hemmingsen et al., 2007; Porter and Trenhaile, 2007; Mayaud et al., 2014). Tidallyinduced wetting and drying is the primary driver of changes in the intertidal zone (Hemmingsen et al., 2007; Porter and Trenhaile, 2007), however its importance decreases with elevation where subaerial microclimates, such as temperature and humidity become more important in driving surface changes (Gómez-Pujol et al., 2007; Mayaud et al., 2014). In the supratidal zone, interaction with biofilms, such as endolithic biofilms can be a determinate of surface changes (Gómez-Pujol et al., 2007). For example on coastal sandstone cliffs in Victoria, Australia, it was hypothesised that the rock surface expanded 
and contracted with the hydration and dehydration of hyphae (Gómez-Pujol et al., 2007). While in supratidal limestones of the Massif des Calanques, France, biofilms amplified the magnitude of microtopographic change events (Mayaud et al., 2014).

Research to date on rock surface changes have focussed on hourly measurements completed over a tidal cycle or compared single measurements separated by months or years. All these TMEM measurements are taken during daylight hours and then used to infer landscape change over annual to decadal periods. Surface movement during the day is however variable and its dynamics over 24 hours, especially in the evening is unknown. Therefore, extrapolating daylight measurements to annual scales without consideration of how the surface behaves over a full 24 hours is problematic, potentially. In this study we quantify the temporal and spatial pattern of surface changes over 3.5 days. The aims of this study are firstly to determine the time of day when the surface is most dynamic, and secondly to test the significance of environmental conditions driving short-term surface change on supratidal rocks.

\section{Study area}

Marengo ( $\left.38^{\circ} 47^{\prime} \mathrm{S}, 143^{\circ} 40^{\prime} \mathrm{E}\right)$ is located on the southwest coast of Victoria, Australia

(Figure 1). It lies in the flanks of the Otway Ranges, and is composed of Lower Cretaceous sandstones and mudstones (Tickell et al., 1992). Schmidt hammer (L-type) rebound values of the rock at Marengo platform vary from 32.8 to 36.0 (Thornton and Stephenson, 2006). The bedrock is composed of well-sorted, fine-grained sandstone (2 to 4 phi) with a 
low porosity $(10.59 \pm 1.17 \%)$ (Gómez-Pujol et al., 2007). The main components include volcanic fragments, quartz and other clay minerals. From scanning electron microscope (SEM) observation, widespread lithobiontic biofilms were identified as being concentrated below the rock surface, with hyphae penetrating down to a few millimetres (Gómez-Pujol et al., 2007).

The coast is a high energy swell and storm wave environment (Edwards, 1941), receiving swells from the Southern Ocean (Gill, 1977). The local wave power (25 - $35 \mathrm{~kW} / \mathrm{m})$ is the highest in Australia, delivering 800 - $1100 \mathrm{GJ} / \mathrm{m}$ of energy in an average year (Hughes and Heap, 2010). Marengo Bay has a microtidal regime with a mean tidal range of $1.05 \mathrm{~m}$ and a range of $1.52 \mathrm{~m}$ during spring tides (PoM, 2013). Annual rainfall at Marengo is approximately $1000 \mathrm{~mm}$; mean daily maximum temperatures range from $21.9^{\circ} \mathrm{C}$ in January to $13.1^{\circ} \mathrm{C}$ in July and mean daily minimum temperatures range from $14.6^{\circ} \mathrm{C}$ in February to $7.3^{\circ} \mathrm{C}$ in July (BoM, 2016). During summer, daily maximum temperatures can exceed $40^{\circ} \mathrm{C}$ (BoM, 2016). Frosts do not occur along this coast.

The study shore platform located $100 \mathrm{~m}$ westward of Hayley Point (Marengo) is $90 \mathrm{~m}$ wide with an average elevation of $1.01 \mathrm{~m}$ relative to mean sea level. The seaward edge of the platform presents an abrupt low tide cliff, about $2 \mathrm{~m}$ in height (Figure 2). The rate of downwearing on shore platform ranges from 0.21 to 0.90 mm/yr (Gill and Lang, 1983; Stephenson et al., 2012). 


\section{Methods}

The traversing micro-erosion meter $($ TMEM) site $(15 \times 15 \times 15 \mathrm{~cm})$ used in this study was located on a supratidal landward cliff, about $2 \mathrm{~m}$ above the shore platform (Figure 2). This site was installed by Gómez-Pujol et al. (2007) and was reoccupied in order to allow direct comparison between their results and this study. The TMEM site was relatively flat but with a small (about $5 \times 4 \mathrm{~cm}$ ) indentation in the apex of the triangular site (Figure 3(a)). A total of 69 coordinates were obtained with the TMEM, within a trapezoidal area of $30.00 \mathrm{~cm}^{2}$ (Figure 3(b)).

In this study, three separate continuous observations were conducted from 8 to 11 November 2016 (late spring) in order to understand surface movements at multiday scale (Figure 4). The first and second observations were conducted on 8 and 9 November 2016 when readings were taken every 2 hours from 06:00 to 22:00 (Australian Eastern Daylight Time, UTC+11) covering sunrise to sunset. To explore surface behaviours in the evening, a third continuous 30-hour observation was conducted from 06:00 10 November to 12:00 11 November 2016. Therefore, over the entire 3.5 days, rock surface behaviours in the morning (06:00 - 12:00) were recorded four times, while surface movements from 12:00 to 22:00 were recorded three times. Movements from 22:00 to 06:00 were monitored only once during the evening from 10 to 11 November 2016. SURFER 13 (Golden Software LLC) was used to generate contour plots and calculate volumetric changes on the rock surface (based on Simpson's 3/8 rule). 
Instrument error was calculated in the laboratory by repeated measurements on a sandstone block taken from the field site. Considering the instrumentation uncertainty in TMEM measurements (Stephenson et al., 2004), a threshold value of $0.01 \mathrm{~mm}$ from Gómez-Pujol et al. (2007) was used to determine the significance of elevational change between successive readings. That is, readings with less than $0.01 \mathrm{~mm}$ of movement were considered to be within instrument error and treated as such.

Air temperature and relative humidity were recorded every five minutes using a $\mathrm{HOBO}^{\circledR}$ Pro v2 data logger shaded from direct sunlight adjacent to the TMEM site. This air suspended data logger was attached to the end of a wood support, positioned $1 \mathrm{~m}$ above the TMEM site and $2 \mathrm{~m}$ off the back rock wall. Rock surface temperature was measured in the centre of the TMEM sites using an infrared thermometer (QM 7220 Digitech) before each set measurements were taken. Additional weather conditions, such as precipitation and cloud cover were noted visually.

\section{Results}

\section{Environmental conditions}

At the TMEM site air temperature varied by $8.7^{\circ} \mathrm{C}$ from 8.2 to $16.9^{\circ} \mathrm{C}$, while rock surface temperature varied by $27^{\circ} \mathrm{C}\left(9-36^{\circ} \mathrm{C}\right)$ (Figure 5). Relative humidity varied by $36.1 \%$ from 55.1 to $91.2 \%$ (Figure 5). Generally, air and rock surface temperatures increased in the morning and decreased in the afternoon. An inverse pattern was observed in humidity with a decrease in the morning and increase in the afternoon. In the evening, the conditions 
were relatively stable with only slight fluctuations occurring in these environmental factors, namely $3.9^{\circ} \mathrm{C}$ for air and $3^{\circ} \mathrm{C}$ for rock surface temperatures and $15.5 \%$ for relative humidity.

The sky condition was changeable throughout the study (Table 1). Partly and mostly cloudy conditions were commonly observed while fully cloudy or cloud free weather occurred for only a few hours. The passing cloud was opaque enough to produce shadows during the day. Only on the morning of 11 November 2016 were cloudy and mostly cloudy conditions dominant.

Hourly rock surface change

Median values of surface changes in units of millimetre were used to summarize the data because statistical mean values of spatial topographical variations are often misleading in these type of studies (Spencer, 1981). The median is a more appropriate measure of central tendency of hourly surface movement to represent microtopographic change patterns (Stephenson et al., 2004). The magnitude of median surface movements varied from -0.050 to $+0.041 \mathrm{~mm}$ over 3.5 days. Stephenson et al. (2004) indicated that differences below $0.010 \mathrm{~mm}$ must be considered with caution and $64.5 \%$ of the median values in this study exceeded this threshold, so can be considered measureable changes. Compared with median values, the maximum single point movement was one order of magnitude higher. The maximum positive movement was of $+0.371 \mathrm{~mm}(14: 00-16: 0010$ November 2016) and the negative of $-0.287 \mathrm{~mm}(20: 00$ - 22:00 9 November 2016). 
Since the relative height of a coordinate at a reading is dependent on the position at the previous reading, a Friedman two-way analysis of variance (ANOVA) by ranks was used to assess if there were significant microtopographic changes during a day (Matthews, 1981). For this test the relative height of each coordinate was ranked against the previous reading over each 2-hour interval. The null hypothesis, that there was no significant variation in short-term microtopography, was rejected in each observation (8 November $2016\left[\chi_{r}^{2}=\right.$ 166.74]; 9 November $2016\left[\chi_{r}^{2}=100.71\right] ; 10$ and 11 November $2016\left[\chi_{r}^{2}=253.59\right] ; P<$ 0.001). Therefore, there were significant changes in microtopography over 2-hourly measurements.

A Wilcoxon matched-pair rank test was then used to examine the temporal homogeneity of surface changes (Matthews, 1981). For each observation, every set of differences in relative height between two successive measurements was compared with all the other sets throughout the observation, generating 28 comparisons on 8 and 9 November 2016 each and 105 comparisons on 10 and 11 November 2016. Overall, the null hypothesis that there was no difference between two sets of data was rejected in $65 \%$ of cases (104/161), which suggested the rock surface was more likely to behave as a heterogenous body throughout the observation period. However, within each observation period, the homogeneity of rock surface changes could be significant $(P>0.05)$ during some consecutive intervals. These specific periods occurred in the morning (06:00 - 12:00 11 November 2016), afternoon (12:00 - 22:00 8 November 2016) and evening (22:00 10 November - 06:00 11 November 2016). The largest $P$-value (>0.9) in the Wilcoxon test was observed in the evening, when $P$-values greater than 0.5 were commonly tested. 
Distinct 'hotspots' of expansion and contraction were observed, indicating the spatial heterogeneity of 2-hourly microtopographic changes (Figure 6). On 8 November 2016, the rock surface was divided into three zones (top, middle and bottom) by different patterns of movement. The bottom zone generally contracted throughout the observation period. The middle zone expanded from 06:00 to 08:00, while the top zone contracted. When the middle zone subsequently contracted, the top zone expanded. Except for a widespread contraction from $10: 00$ to $12: 00$ and stability from $20: 00$ to $22: 00$, the alternation between expansion and contraction was observed on these two zones through the afternoon (12:00 - 20:00). On 9 November 2016, the rock surface changed in a similar pattern to the previous morning but more heterogenuously in the afternoon. On 10 November 2016, from 06:00 to 10:00, contraction dominated the surface, while stability was the main trend throughout the evening of 10 November 2016. Continuous and homogenous contraction was then observed on the last morning (11 November 2016). Overall, all the intrevals from 06:00 to $08: 00$ were characterized by contraction, while intervals from $18: 00$ to $20: 00$ by expansion.

Rock surface movements over 2-hourly measurements are classified into falling, rising and stable (Figure 5). On 8 November 2016, falling was the primary movement in the day, while rising points increased and falling points declined after 12:00. The only period when stability dominated was from 20:00 to $22: 00$. Falling and rising were the most frequent movements on 9 November 2016 but more falling points occurred in the morning (06:00 12:00) and more rising points in the afternoon (12:00 - 20:00). On 10 November 2016, falling points were dominant from 06:00 to 10:00, followed by a rising period to $20: 00$. 
During the nocturnal measurements, stable points dominated consecutively between 22:00 10 November and 06:00 11 November 2016. The dominance of falling points repeated on the morning of 11 November 2016.

In general, there appeared to be more falling points in the morning, more rising points in the afternoon and more stable points in the evening (Table 2). As a result, a day could be divided into three periods: falling (06:00 - 12:00), rising (12:00 - 20:00) and stable (20:00 06:00). A chi-squared test was then used to assess if there was any difference in movement between the three periods. The null hypothesis that there was no difference in point movement among the three periods was rejected $\left(x^{2}=281.9, P<0.001\right)$.

Consequently, there were significant differences in the numbers of falling, rising and stable points measured over the three periods.

\section{Daily rock surface change}

To investigate multiday surface change, the contour graph of height variations between the first (06:00 8 November 2016) and last (12:00 11 November 2016) measurements was plotted (Figure 7). To exclude the variations caused by measuring at different hours, surface changes between two 06:00 (8 and 11 November 2016), and two 12:00 (8 and 11 November 2016) were also plotted (Figure 7). Most of the area had contracted by $c .0 .1$ $\mathrm{mm}$ since the first set of measurements, with the middle zone contracting by $0.2 \mathrm{~mm}$. Between two 06:00, the rock surface appeared to contract homogenuously by less than 
$0.1 \mathrm{~mm}$. Compared with the change over 3.5 days, the 3-day variation between two 12:00 showed a similar pattern albeit of a lower magnitude.

In order to take into account the net surface movement, volumetric change of the rock surface was also measured throughout the entire field study (Figure 8). The values were calculated with relative height data and therefore determined as $0 \mathrm{~cm}^{3}$ when all probe readings were of $0 \mathrm{~mm}$. Generally, the volume fluctuated between observations. In a full 24 hours, the highest volumes occurred twice at 06:00 and 20:00 respectively. After a stable period in the evening, volume reduced continuously on 11 November 2016. Within a 24-hour period, the highest contraction of $0.29 \mathrm{~cm}^{3}$ occurred between 06:00 and 10:00 on 10 November 2016; while the highest expansion was measured between 10:00 and 20:00 on the same day, with an increase of $0.26 \mathrm{~cm}^{3}$. At multiday scale, a net contraction by 0.42 $\mathrm{cm}^{3}$ was measured between the first and last recordings. Divided by the area, this change is equivalent to a fall of $0.140 \mathrm{~mm}$ on average across the rock surface. Comparing the measurments at the same hour on 8 and 11 November 2016, the TMEM site contracted by $0.25 \mathrm{~cm}^{3}$ (0.085 $\mathrm{mm}$ in elevation) between two $06: 00$ and $0.23 \mathrm{~cm}^{3}(0.076 \mathrm{~mm}$ in elevation) between two 12:00.

Doubts arise about the independence of observations in the short-term rock surface change study. Gómez-Pujol et al. (2007) indicated that the measured points do not suffer from spatial autocorrelation due to the large difference in order of magnitude between the TMEM vertical resolution and the horizontal separation. Despite temporal autocorrelation in the surface movement $\left(x^{2}=281.9, P<0.001\right)$, it is a typical feature related to the "microtopography surface change" that the surface movement is a function of the previous 
movement. Linear regression is still used to explore the influence of environmental factors on rock surface change trends (Mayaud et al., 2014). There were significant relationships between 2-hourly median height difference and relative humidity difference $\left(R^{2}=0.27\right)$ and median height difference and air temperature difference $\left(\mathrm{R}^{2}=0.24\right)$ at Marengo. By crossing the $x-y$ intercept, the TMEM site showed expansion with increasing humidity and contraction with decreasing humidity (Figure 9(a)). In contrast, an inverse pattern was observed in response to air temperature variations (Figure 9(b)). However, no particular relationship was displayed between surface variation and rock surface temperature difference (Figure 9(b)).

\section{Discussion}

Temperature and humidity are key controls on the rates and types of rock decay processes that act on rock surfaces (Turkington and Paradise, 2005). They determine the rate at which chemical reactions take place as well as the dynamics of flora and fauna inhabiting rock surfaces (Trenhaile, 1987; Stephenson and Kirk, 1998). At a global scale this is observed in much greater rates of chemical weathering at low latitudes compared with high latitudes which are dominated by physical processes (Trenhaile, 2002; Trenhaile, 2006). At the smaller scale of a single rock outcrop in temperate Australia, rock surface behaviour was observed to be strongly correlated to variations in temperature and humidity. For example, at the field site, the rock surface expansion and contraction was directly related to the respective rise and fall in humidity. A change of $18 \%$ in relative 
humidity was enough to induce significant movement (Figure 9(a)). In contrast, surface movement in response to temperature variations was inverse that of humidity, with a negative relationship between surface movement and air temperature. A threshold of $6^{\circ} \mathrm{C}$ change in air temperature was enough to trigger surface movement (Figure 9(b)). Thermal stress has been proposed as the driver of surface changes on supratidal limestone in the Calanques, France, at which net expansion up to $0.4 \mathrm{~mm}$ occurred over daily observations (Mayaud et al., 2014). However, at Marengo during the warmest period of the day (10:00 16:00), the rock surface remained dynamic even though air temperature fluctuations were $<1^{\circ} \mathrm{C}$. The implication of this dynamism during a relative stable temperature period is that relative humidity, and therefore moisture, is the primary driver of rock surface change.

Insolation also plays a role in driving rock surface changes by influencing humidity and temperature on the rock surface. In the field, the rock surface tended to contract at sunrise (06:00), reach the maximum contraction at the peak of solar insolation (12:00) and then expand with decreasing light intensity until sunset (20:00). During the evening, it remained stable in the absence of light.

Compared with relative humidity and air temperature, rock surface temperature is a complementary information source in this study. The temperature gradient between rock surface and subsurface causes the stressing of rock and ultimately rock decay through thermal fatigue effects (Warke et al., 1996; Warke and Smith, 1998). It can be amplified under varying windspeed and cloud cover or with large temperature differences between rock and air (Jenkins and Smith, 1990; Hall and Hall, 1991). The interaction of colonized organisms on rock surfaces can increase the temperature gradient due to their low thermal 
conductivity and high albedo (Warke et al., 1996). These factors may be partially responsible for more frequent occurrences of expansion and contraction of rock surface during the day. The influence of temperature gradient can be quantified in any future studies by monitoring rock temperature at different depths.

The main mechanism of moisture-driven rock surface expansion is likely to be due to water being absorbed by clay minerals (Trenhaile, 2006) and lithobiontic biofilms (GómezPujol et al., 2007), as well as creating disjoining pressure (Ruedrich et al., 2011). For example, at Kaikōura, New Zealand, tidal wetting and drying has been identified as the primary driver for surface microtopographic changes on shore platforms in mudstone (Stephenson and Kirk, 2001; Hemmingsen et al., 2007). On intertidal rock surfaces at Kaikōura Peninsula, New Zealand and Apollo Bay, Australia (6 km north of and in the same geology as this study), daily contraction and expansion of $0.037 \mathrm{~mm}$ was inferred to be caused by moisture uptake by clay minerals when tidally immersed (Stephenson et al., 2004). In this study, the maximum surface movement ranged from -0.287 to $+0.371 \mathrm{~mm}$, $60 \%$ higher than the range $(-0.126$ to $+0.261 \mathrm{~mm})$ recorded by Gómez-Pujol et al. (2007) at the same site. Median values of expansion and contraction $(-0.05$ to $+0.04 \mathrm{~mm})$ from this study are of the same order of magnitude as the mean diameter of hyphae penetrating the rock surface (Gómez-Pujol et al., 2007). The correlation of rock expansion and hyphal width is suggestive of a causative mechanism; however controlled laboratory experiments are required to demonstrate biofilms as the driver of surface changes.

The pattern of surface behaviour between this study and Gómez-Pujol et al. (2007) at the same site are however different. In the earlier work it was observed that a high proportion 
of the points remained stable during the day, while during this study the rock surface behaved dynamically. The temperature and humidity fluctuations between the two studies were similar (t-test, $P>0.05$ ); however the cloud conditions differed. Overcast days were dominant during this study while during that of Gómez-Pujol et al. (2007) it was mostly sunny (Gómez-Pujol pers. comm.). Small amount of passing cloud are known to cause thermal variations by interrupting insolation (Carter and Viles, 2004; Coombes, 2011) and provide a low light environment suitable for the physiological activity of biofilms on rock surfaces (Lange et al., 1990). This would have likely caused the different patterns observed between both studies.

The rock surface behaviour was highly dynamic at 2-hourly scale, repeatedly falling and rising by up to -0.287 to $+0.371 \mathrm{~mm}$. The change pattern was also characterised by its spatial heterogeneity with expansion and contraction at centimetre scale tending to occur concurrently across the rock surface. More occurrences of contraction occurred in the morning (06:00 - 12:00) whilst expansion occurred in the afternoon (12:00 - 20:00) in response to microclimatic changes. Due to the more constant microclimate over night (20:00 - 06:00), the rock surface was relatively stable.

At daily scale, there was no net elevational change on the rock surface (Figure 10(a)). Periods of contraction when the rock surface reached its lowest position, were matched by the subsequent expansion where the rock surface lifted and reverted to its initial position. This position was then maintained over the subsequent stable period; therefore the aggregated impact from different periods within a day on rock surface elevation is negligible. It is similar to the single observation period of Gómez-Pujol et al. (2007) at 
Marengo when the site was sunny (total expansion of $0.005 \mathrm{~mm}$ in 0.8 days) (06:00-22:00) and at Apollo Bay, $8 \mathrm{~km}$ northeast from Marengo, where net daily rock surface movement was measured at $<0.01 \mathrm{~mm}$ (Stephenson et al., 2004).

Gómez-Pujol et al. (2007) suggested undertaking TMEM measurements at the peak of solar heating when the maximum surface contraction occurred. During this 3.5-day study, daily volumetric changes ranging from -0.15 to $-0.02 \mathrm{~cm}^{3}$ were calculated by comparing readings taken at midday (12:00), equivalent to an average elevation change from -0.051 to $-0.006 \mathrm{~mm}$ (Figure 8 ). In contrast, the daily change in the evening (20:00) was of a lower magnitude (from -0.011 to $-0,008 \mathrm{~mm}$ in elevation) close to instrument error $( \pm 0.010$ $\mathrm{mm}$ ), indicating TMEM measurements taken after sunset are more eligible for standardizing data. As a result of the unstable environmental conditions during the day, due to the interruption by passing clouds and wind gusts, the maximum contraction may not occur at the sunniest hour. Therefore comparing measurements at the peak of solar heating between different days is likely to be influenced by hourly surface changes. While the rock surface can recover from microtopographic change in the evening and remain stable due to the constant microclimate, ensuring data taken from different days would be of greater use.

At multiday scale, in this study, a net contraction of $0.140 \mathrm{~mm}$ over 3.5 days occurred (Figure 10(b)). The experiment started in the early morning and ended at midday which was when contraction generally occurred. Excluding this contraction period from the analysis yields an overall lowering of around $0.080 \mathrm{~mm}$ over 3 days. This rate of contraction was approximately a quarter of the annual downwearing $(0.31 \mathrm{~mm})$ rate on the 
intertidal surface of the Marengo shore platforms based on 30 years of data (Stephenson et al., 2012). Intertidal surfaces are generally the areas of highest downwearing (Stephenson and Kirk, 2000; Kanyaya and Trenhaile, 2005), so the question therefore arises as to whether this measured lowering represents actual erosion. If it is erosion then the implication is downwearing at the granular-scale is concentrated into narrow windows of time. Given the weather conditions were mild during this study and were not conducive to grain removal (i.e. little wind and no rain), it is more likely that the lowering observed is a function of volumetric change in the near-surface bedrock. The scale of this volumetric change therefore is important for understanding long-term rates of downwearing. Firstly the observed 2-hourly movement has to be contextualised within longer (diurnal) patterns of rock surface behaviour. The results from this study appear to indicate that multiday scale cycles of rock surface movement may occur. The second implication is that rock surface behaviours varied during the day. Studies of long-term downwearing therefore need to account for this change. For example individual measurements a year apart, but taken during different weather conditions, may only reflect the short-term dynamism rather than a long-term trend. To have a better understanding of the influence of environmental factors on short-term rock surface change, future work could be conducted in the laboratory with an environmental chamber keeping one variable varying during TMEM measurements while the other variable constant. Continuous temperature scanning of the rock surface and near-surface rock temperature gradients during MEM measurements should also be considered in the field and laboratory experiments. 


\section{Conclusions}

Significant relationships were found between the 2-hourly surface movement and relative humidity difference $\left(R^{2}=0.27\right)$ and air temperature difference $\left(R^{2}=0.24\right)$ on a supratidal rock surface at Marengo. Two-hourly rock microtopographic change was determined by fluctuating microclimate, with humidity playing the primary role. A change of $18 \%$ in relative humidity caused the rock surface to expand with increasing humidity and contract with decreasing humidity. With the interruption of cloud, the rock surface remained active in the day. Therefore, the rock surface behaviour was highly dynamic at 2-hourly scale, repeatedly falling and rising by up to $0.644 \mathrm{~mm}$. Two-hourly surface change was also characterised by the spatial heterogeneity, with contraction and expansion occurring concurrently at centimetre scale across the rock surface.

Associated with 2-hourly surface movement, the rock surface underwent no net microtopographic loss of material at daily scale. Based on surface changes measured over a 24-hour period the pattern of changes could be divided into three periods: falling (06:00 12:00), rising (12:00 - 20:00) and stable (20:00 - 06:00). In contrast, an overall contraction was observed at multiday scale, behaving more spatially homogeneously across the rock surface. The temporal scale of rock surface behaviour is therefore complex. Cycles of expansion and contraction appear to occur over hourly to multiday scales and likely even longer. Long-term monitoring of rock surface behaviour therefore needs to account for local weather during each measurement so as to remove short-term expansion and contraction from long-term erosion rates. 


\section{Acknowledgements}

This work was partly funded by the Australian Research Council Linkage Program (Grant \#ARC-LP130100204). Hanna Kowalczyk and Thomas Savige are thanked for assistance in the field.

\section{References}

BoM, 2016. Long-term temperature record. Bureau of Meteorology: Canberra.

Brantley SL. 2010. Weathering: Rock to regolith. Nature Geoscience 3: 305.

Carter NEA, Viles HA. 2004. Lichen hotspots: raised rock temperatures beneath Verrucaria nigrescens on limestone. Geomorphology 62: 1-16.

Coombes MA. 2011. Rock warming and drying under simulated intertidal conditions, part I: experimental procedures and comparisons with field data. Earth Surface Processes and Landforms 36: 2114-2121.

Edwards AB. 1941. Storm wave platforms. Journal of Geomorphology 4: 223-236.

Gill ED, Lang J. 1983. Micro-erosion meter measurements of rock wear on the Otway coast of southeast Australia. Marine Geology 52: 141-156.

Gill ED. 1977. Evolution of the Otway coast, Australia, from the last interglacial to the present. Proceedings of the Royal Society of Victoria 89: 7-18.

Gómez-Pujol L, Fornós JJ, Swantesson JO. 2006. Rock surface millimetre-scale roughness and weathering of supratidal Mallorcan carbonate coasts (Balearic Islands). Earth Surface Processes and Landforms 31: 1792-1801.

Gómez-Pujol L, Stephenson WJ, Fornós JJ. 2007. Two-hourly surface change on supratidal rock (Marengo, Victoria, Australia). Earth Surface Processes and Landforms 32: 1-12. 
Hall K, Hall A. 1991. Thermal gradients and rock weathering at low temperatures: some simulation data. Permafrost and Periglacial Processes 2: 103-112.

Hemmingsen SA, Eikaas HS, Hemmingsen MA. 2007. The influence of seasonal and local weather conditions on rock surface changes on the shore platform at Kaikōura Peninsula, South Island, New Zealand. Geomorphology 87: 239-249.

Hughes MG, Heap AD. 2010. National-scale wave energy resource assessment for Australia. Renewable Energy 35: 1783-1791.

Jenkins K, Smith B. 1990. Daytime rock surface temperature variability and its implications for mechanical rock weathering: Tenerife, Canary Islands. Catena 17: 449-459.

Kanyaya JI, Trenhaile AS. 2005. Tidal wetting and drying on shore platforms: an experimental assessment. Geomorphology 70: 129-146.

Kennedy DM, Paulik R, Dickson ME. 2011. Subaerial weathering versus wave processes in shore platform development: reappraising the Old Hat Island evidence. Earth Surface Processes and Landforms 36: 686-694.

Lange OL, Meyer A, Zellner H, Ullmann I, Wessels D. 1990. Eight days in the life of a desert lichen: water relations and photosynthesis of Teloschistes capensis in the coastal fog zone of the Namib Desert. Madoqua 17: 17-30.

Luquot L, Roetting TS, Carrera J. 2014. Characterization of flow parameters and evidence of pore clogging during limestone dissolution experiments. Water Resources Research 50: 6305-6321.

Matthews JA. 1981. Quantitative and statistical approaches to geography: a practical manual. Pergamon press: Oxford.

Mayaud JR, Viles HA, Coombes MA. 2014. Exploring the influence of biofilm on short-term expansion and contraction of supratidal rock: an example from the Mediterranean. Earth Surface Processes and Landforms 39: 1404-1412.

Naylor LA, Stephenson WJ. 2010. On the role of discontinuities in mediating shore platform erosion. Geomorphology 114: 89-100.

PoM, 2013. Victorian Tide Tables, 88th edn. Port of Melbourne Corporation: Melbourne.

Porter NJ, Trenhaile AS. 2007. Short-term rock surface expansion and contraction in the intertidal zone. Earth Surface Processes and Landforms 32: 1379-1397. 
Porter NJ, Trenhaile AS, Prestanski KJ, Kanyaya JI. 2010. Shore platform downwearing in eastern Canada: micro-tidal Gaspe, Quebec. Geomorphology 116: 77-86.

Ruedrich J, Bartelsen T, Dohrmann R, Siegesmund S. 2011. Moisture expansion as a deterioration factor for sandstone used in buildings. Environmental Earth Sciences 63: 1545-1564.

Spencer T. 1981. Micro-topographic change on calcarenites, grand Cayman Island, West Indies. Earth Surface Processes and Landforms 6: 85-94.

Stephenson WJ, Naylor LA. 2011a. Geological controls on boulder production in a rock coast setting: insights from South Wales, UK. Marine Geology 283: 12-24.

Stephenson WJ, Naylor LA. 2011b. Within site geological contingency and its effect on rock coast erosion. Journal of Coastal Research 64: 831-835.

Stephenson WJ, Dickson ME, Trenhaile AS. 2013. Rock Coasts. In Treatise on Geomorphology, Shroder J, Sherman DJ (eds). Academic Press: San Diego; 289-307.

Stephenson WJ, Finlayson BL. 2009. Measuring erosion with the micro-erosion metercontributions to understanding landform evolution. Earth-Science Reviews 95: 53-62.

Stephenson WJ, Kirk RM. 1996. Measuring erosion rates using the micro-erosion meter: 20 years of data from shore platforms, Kaikōura Peninsula, South Island, New Zealand. Marine Geology 131: 209-218.

Stephenson WJ, Kirk RM. 1998. Rates and patterns of erosion on inter-tidal shore platforms, Kaikōura Peninsula, South Island, New Zealand. Earth Surface Processes and Landforms 23: 1071-1085.

Stephenson WJ, Kirk RM. 2000. Development of shore platforms on Kaikōura Peninsula, South Island, New Zealand: Part two: The role of subaerial weathering. Geomorphology 32: 43-56.

Stephenson WJ, Kirk RM. 2001. Surface swelling of coastal bedrock on inter-tidal shore platforms, Kaikōura Peninsula, South Island, New Zealand. Geomorphology 41: 5-21.

Stephenson WJ, Kirk RM, Kennedy DM, Finlayson BL, Chen Z. 2012. Long term shore platform surface lowering rates: Revisiting Gill and Lang after 32years. Marine Geology 299: 90-95. 
Stephenson WJ, Taylor AJ, Hemmingsen MA, Tsujimoto H, Kirk RM. 2004. Short-term microscale topographic changes of coastal bedrock on shore platforms. Earth Surface Processes and Landforms 29: 1663-1673.

Sunamura, T. 1992. Geomorphology of rocky coasts. John Wiley and Sons: Chichester.

Thornton LE, Stephenson WJ. 2006. Rock strength: a control of shore platform elevation. Journal of Coastal Research, 22: 224-231.

Tickell SJ, Abele C, Edwards J. 1992. Port Campbell Embayment: 1: 100000 Map Geological Report. Geological Survey of Victoria 95.

Trenhaile AS. 1972. The shore platforms of the Vale of Glamorgan, Wales. Transactions of the Institute of British Geographers, 56, 127-144.

Trenhaile AS. 1987. The geomorphology of rock coasts. Oxford University Press: Oxford.

Trenhaile AS. 2002. Rock coasts, with particular emphasis on shore platforms.

Geomorphology 48: 7-22.

Trenhaile AS. 2006. Tidal wetting and drying on shore platforms: an experimental study of surface expansion and contraction. Geomorphology 76: 316-331.

Trenhaile AS, Porter NJ. 2018. Shore platform downwearing in eastern Canada; A 9-14 year micro-erosion meter record. Geomorphology 311: 90-102.

Turkington AV, Paradise TR. 2005. Sandstone weathering: a century of research and innovation. Geomorphology 67: 229-253.

Warke P, Smith B. 1998. Effects of direct and indirect heating on the validity of rock weathering simulation studies and durability tests. Geomorphology 22: 347-357.

Warke P, Smith B, Magee R. 1996. Thermal response characteristics of stone: implications for weathering of soiled surfaces in urban environments. Earth Surface Processes and Landforms 21: 295-306. 


\section{Tables}

Table 1: The sky condition at the TMEM site from 8 to 11 November 2016

\begin{tabular}{|c|c|c|c|c|c|c|c|c|c|c|c|c|}
\hline Time & 00:00 & 02:00 & 04:00 & 06:00 & 08:00 & $10: 00$ & $12: 00$ & $14: 00$ & $16: 00$ & $18: 00$ & 20:00 & 22:00 \\
\hline & $\begin{array}{l}- \\
-\end{array}$ & $\begin{array}{lll}- & -1\end{array}$ & - & & Cloudy & Cloudy & & & & & & \\
\hline $\begin{array}{l}9 \text { November } \\
2016\end{array}$ & $\begin{array}{l}- \\
-\end{array}$ & $\begin{array}{ll}- \\
-\end{array}$ & - & & & & & & & Cloudy & & \\
\hline $\begin{array}{l}10 \text { November } \\
2016\end{array}$ & - & - & - & $\begin{array}{l}\text { Mostly } \\
\text { cloudy }\end{array}$ & & & $\begin{array}{l}\text { Partly } \\
\text { cloudy }\end{array}$ & $\begin{array}{l}\text { Partly } \\
\text { cloudy }\end{array}$ & $\begin{array}{l}\text { Mostly } \\
\text { cloudy }\end{array}$ & & & $\begin{array}{l}\text { Mostly } \\
\text { clear }\end{array}$ \\
\hline $\begin{array}{l}11 \text { November } \\
2016\end{array}$ & $\begin{array}{l}\text { Mostly } \\
\text { clear }\end{array}$ & $\begin{array}{c}\text { Mostly } \\
\text { clear }\end{array}$ & Clear & Cloudy & Cloudy & $\begin{array}{l}\text { Mostly } \\
\text { cloudy }\end{array}$ & $\begin{array}{l}\text { Mostly } \\
\text { cloudy }\end{array}$ & 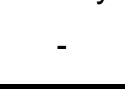 & 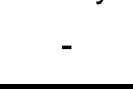 & - & 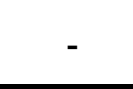 & - \\
\hline
\end{tabular}

Table 2: The percentages of falling, rising, active (in italics, the combination of falling and rising points) and stable points occurring in each interval (\%)

\begin{tabular}{|lccccccccccccc}
\hline Interval & $\mathbf{0 6}$ to $\mathbf{0 8}$ & $\mathbf{0 8}$ to $\mathbf{1 0}$ & $\mathbf{1 0}$ to $\mathbf{1 2}$ & $\mathbf{1 2}$ to $\mathbf{1 4}$ & $\mathbf{1 4}$ to $\mathbf{1 6}$ & $\mathbf{1 6}$ to $\mathbf{1 8}$ & $\mathbf{1 8}$ to $\mathbf{2 0}$ & $\mathbf{2 0}$ to $\mathbf{2 2}$ & $\mathbf{2 2}$ to $\mathbf{0 0}$ & $\mathbf{0 0}$ to $\mathbf{0 2}$ & $\mathbf{0 2}$ to $\mathbf{0 4}$ & $\mathbf{0 4}$ to $\mathbf{0 6}$ \\
\hline $\mathrm{N}$ & $\mathbf{2 7 6}$ & $\mathbf{2 7 6}$ & 276 & 207 & 207 & 207 & 207 & 207 & 69 & 69 & 69 & 69 \\
Falling & 66.7 & 48.6 & 52.2 & 31.4 & 45.4 & 42.0 & 21.7 & 36.7 & 26.1 & 23.2 & 20.3 & 15.9 \\
Rising & 17.4 & 37.0 & 30.8 & 45.4 & 42.0 & 35.3 & 56.5 & 22.7 & 26.1 & 21.7 & 18.8 & 20.3 \\
Active & 84.1 & 85.6 & 83.0 & 76.8 & 87.4 & 77.3 & 78.2 & 59.4 & 52.2 & 44.9 & 39.1 & 36.2 \\
Stable & 15.9 & 14.5 & 17.0 & 23.2 & 12.6 & 22.7 & 21.7 & 40.6 & 47.8 & 55.1 & 60.9 & 63.8 \\
\hline
\end{tabular}




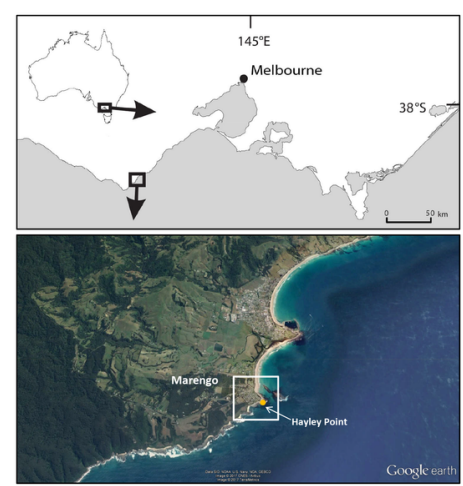

ESP_4476_Figure 1.tif

This article is protected by copyright. All rights reserved. 

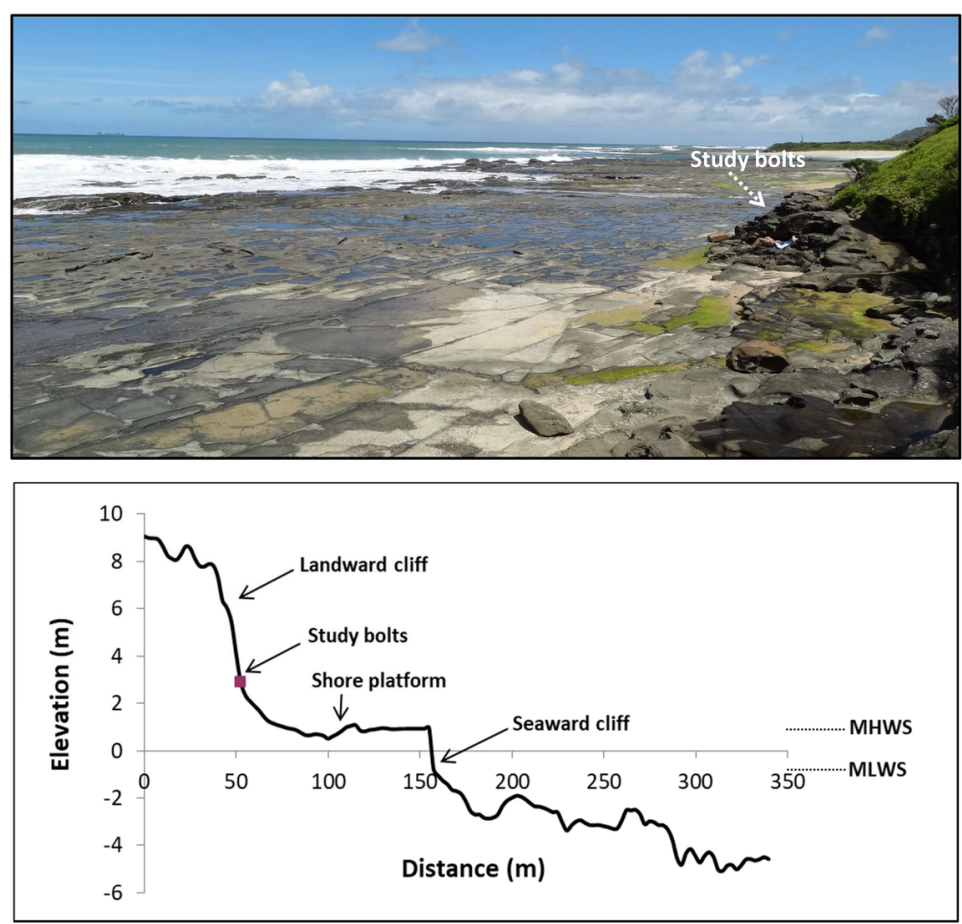

ESP_4476_Figure 2.tif

This article is protected by copyright. All rights reserved. 

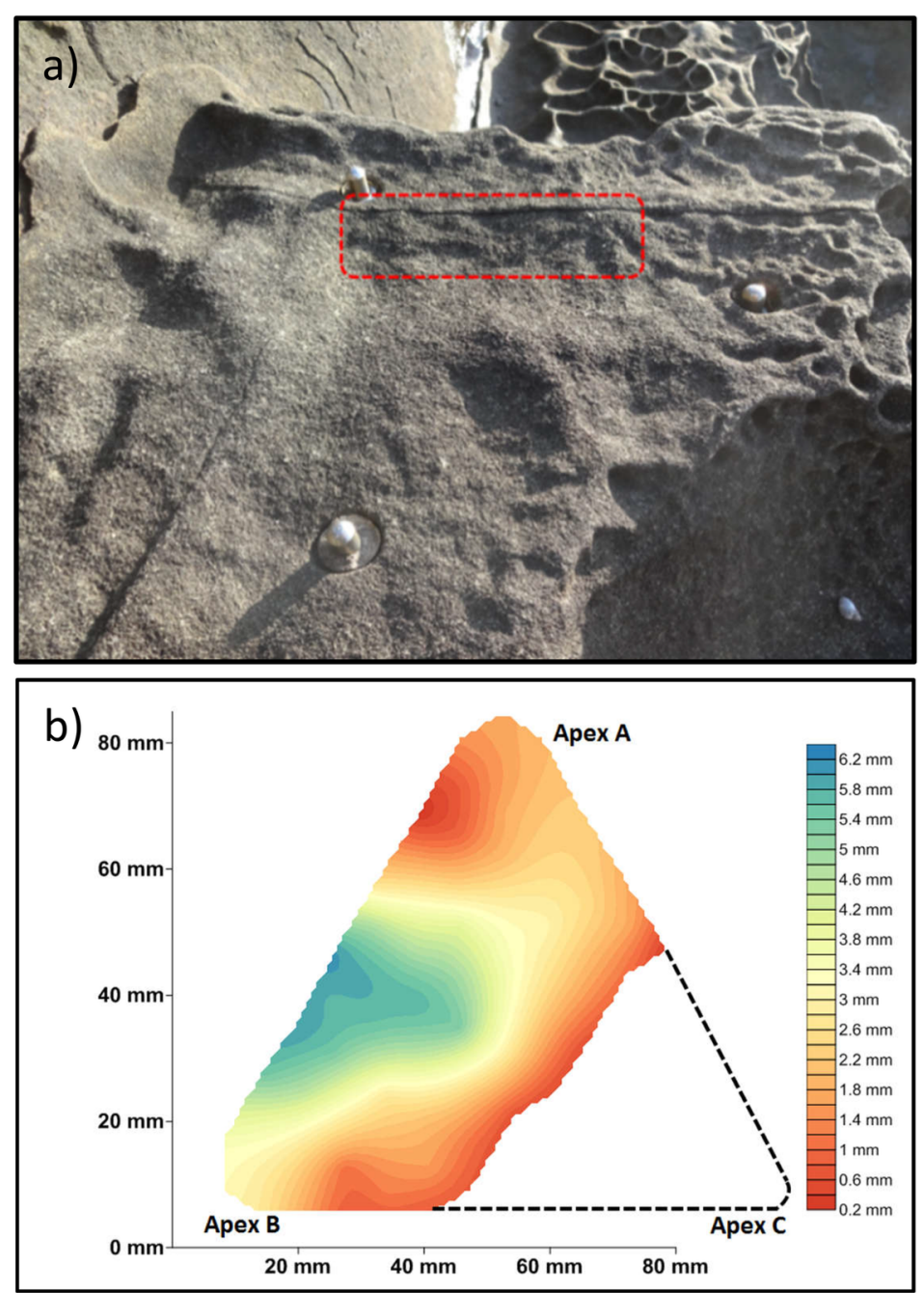

ESP_4476_Figure 3.tif

This article is protected by copyright. All rights reserved. 


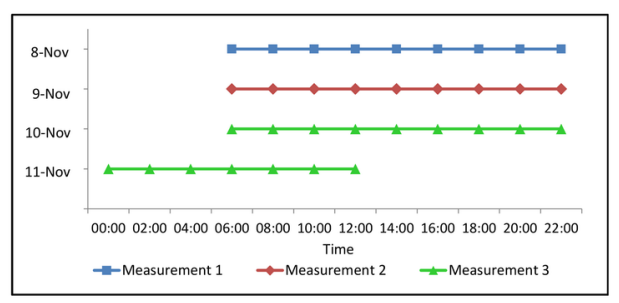

ESP_4476_Figure 4.tif

This article is protected by copyright. All rights reserved. 


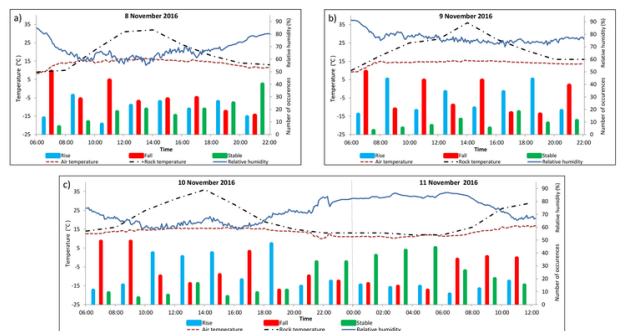

ESP_4476_Figure 5.tif

This article is protected by copyright. All rights reserved. 


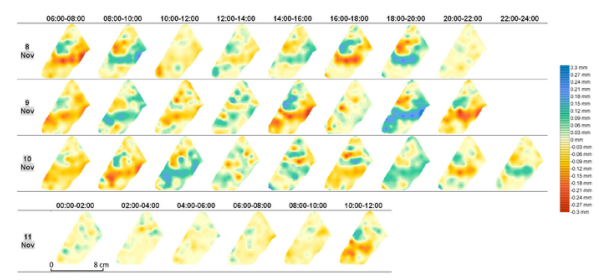

ESP_4476_Figure 6.tif

This article is protected by copyright. All rights reserved. 


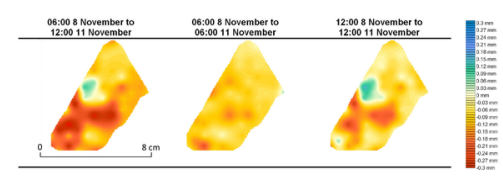

ESP_4476_Figure 7.tif

This article is protected by copyright. All rights reserved. 


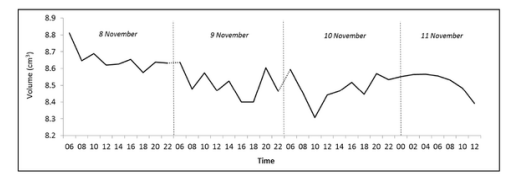

ESP_4476_Figure 8.tif

This article is protected by copyright. All rights reserved. 

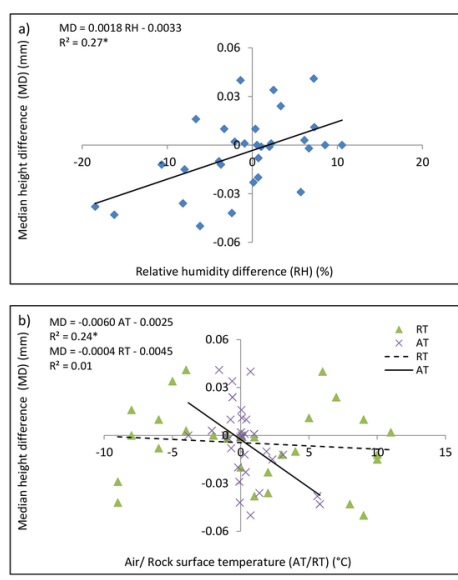

ESP_4476_Figure 9.tif

This article is protected by copyright. All rights reserved. 

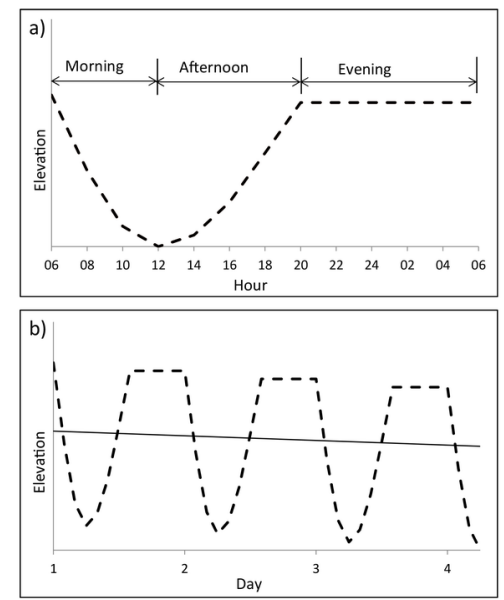

ESP_4476_Figure 10.tif

This article is protected by copyright. All rights reserved. 
Measured with a traversing micro-erosion meter (TMEM), the microtopography of supratidal sandstone was observed to be highly dynamic in response to microclimatic variations at two-hourly scale, primarily driven by the fluctuating humidity. The rock surface underwent no net microtopographic loss of material at daily scale and could be divided into three periods of different movement trends: falling (06:00 - 12:00), rising (12:00 - 20:00) and stable (20:00 - 06:00), while an overall contraction occurred at multiday scale.

Title: Hourly to daily-scale microtopographic fluctuations of supratidal sandstone

Authors: Runjie Yuan*, David M. Kennedy and Wayne J. Stephenson

Figure:

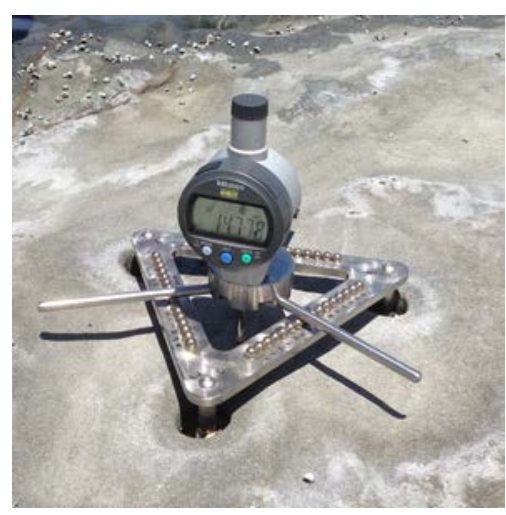

This article is protected by copyright. All rights reserved. 


\section{University Library}

\section{- $\underset{A C C E S S}{M}$ I R VA A gateway to Melbourne's research publications}

Minerva Access is the Institutional Repository of The University of Melbourne

Author/s:

Yuan, R;Kennedy, DM;Stephenson, WJ

Title:

Hourly to daily-scale microtopographic fluctuations of supratidal sandstone

Date:

2018-12-01

Citation:

Yuan, R., Kennedy, D. M. \& Stephenson, W. J. (2018). Hourly to daily-scale

microtopographic fluctuations of supratidal sandstone. EARTH SURFACE PROCESSES AND LANDFORMS, 43 (15), pp.3142-3151. https://doi.org/10.1002/esp.4476.

Persistent Link:

http://hdl.handle.net/11343/284431 